NREL/TP.550.26148

July 1999

\title{
Willingness to Pay for Electricity from Renewable Resources: A Review of Utility Market Research
}

Barbara C. Farhar, Ph.D., National Renewable Energy Laboratory

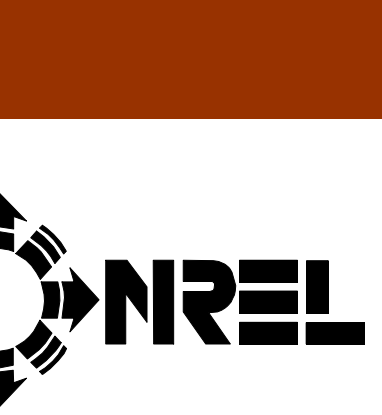

National Renewable Energy Laboratory

A national laboratory of the U.S. Department of Energy

The Topical Issues Brief series is sponsored by

DOE's Office of Energy Efficiency and Renewable Energy

Office of Power Technologies 


\section{NOTICE}

This report was prepared as an account of work sponsored by an agency of the United States government. Neither the United States government nor any agency thereof, nor any of their employees, makes any warranty, express or implied, or assumes any legal liability or responsibility for the accuracy, completeness, or usefulness of any information, apparatus, product, or process disclosed, or represents that its use would not infringe privately owned rights. Reference herein to any specific commercial product, process, or service by trade name, trademark, manufacturer, or otherwise does not necessarily constitute or imply its endorsement, recommendation, or favoring by the United States government or any agency thereof. The views and opinions of authors expressed herein do not necessarily state or reflect those of the United States government or any agency thereof.

Printed in the United States of America

Available to DOE and DOE contractors from:

Office of Scientific and Technical Information (OSTI)

P.O. Box 62

Oak Ridge, TN 37831

Prices available by calling 423-576-8401

Available to the public from:

National Technical Information Service (NTIS)

U.S. Department of Commerce

5285 Port Royal Road

Springfield, VA 22161

703-605-6000 or 800-553-6847

or

DOE Information Bridge

http://www.doe.gov/bridge/home.html 


\section{Contents}

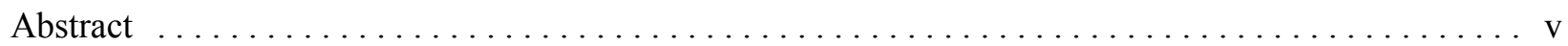

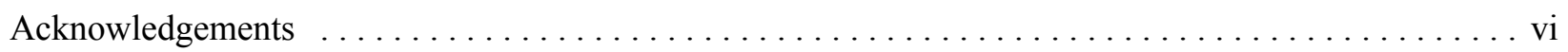

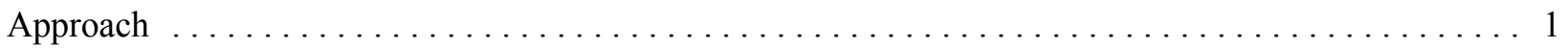

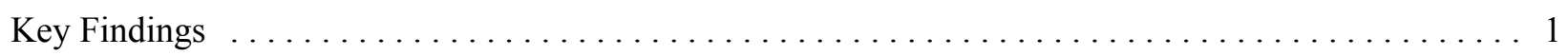

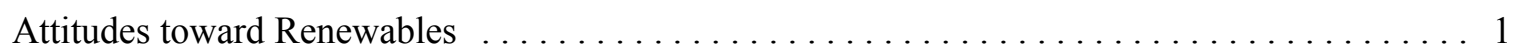

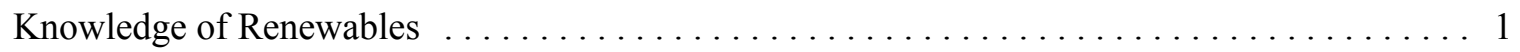

Stated Likelihood of Voluntarily Paying for Electricity from Renewable Resources . . . . . . . 2

Stated Willingness to Pay More for Renewable Electricity by Residential Customers . . . . . . 2

An Aggregated Residential Customer Willingness-to-Pay Curve $\ldots \ldots \ldots \ldots \ldots \ldots \ldots \ldots . \ldots 2$

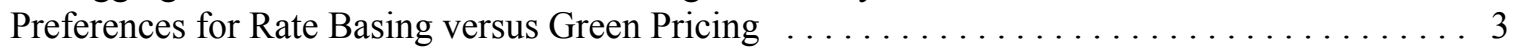

Willingness to Pay for Power from Renewables in Competitive Markets . . . . . . . . . 4

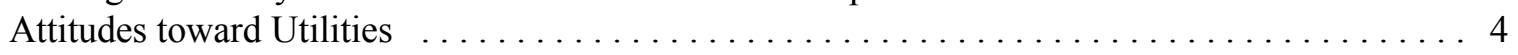

National Poll Data and Other Recent Market Research Findings . . . . . . . . . . . . . 4

Attitudes toward and Knowledge of Renewables $\ldots \ldots \ldots \ldots \ldots \ldots \ldots \ldots \ldots \ldots$

Willingness to Pay More for Electricity from Renewable Sources $\ldots \ldots \ldots \ldots \ldots \ldots \ldots . \ldots$

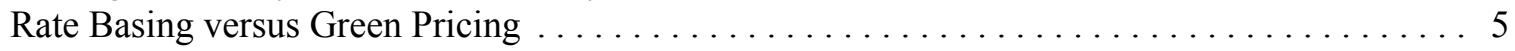

Attitudes toward Utility Companies as Suppliers of Electricity from Renewable Sources . . . . 5

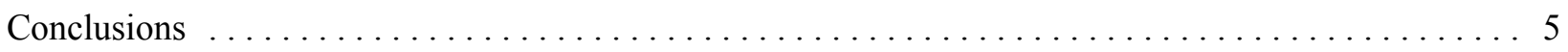

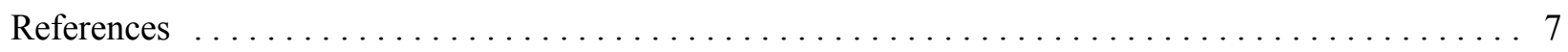

Appendix A: Data on Attitudes toward and Knowledge of Renewables $\ldots \ldots \ldots \ldots \ldots \ldots \ldots$

Attitudes toward Renewables $\ldots \ldots \ldots \ldots \ldots \ldots \ldots \ldots \ldots \ldots \ldots \ldots \ldots$

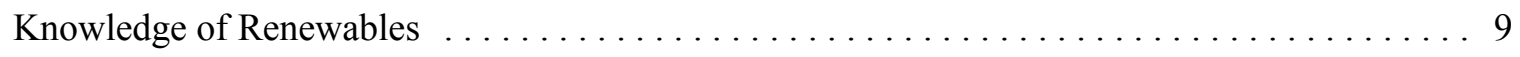

Appendix B: Data on Customer Interest in Paying More for Electricity from Renewable Sources . . . 10

Stated Likelihood of Paying More for Renewables $\ldots \ldots \ldots \ldots \ldots \ldots \ldots \ldots \ldots \ldots$

Stated Willingness to Pay More for Electricity from Renewable Sources by

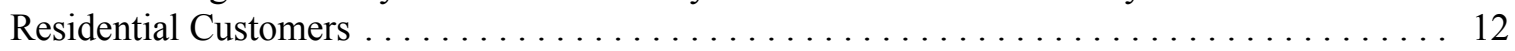

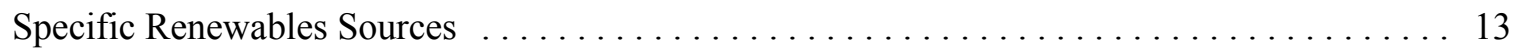

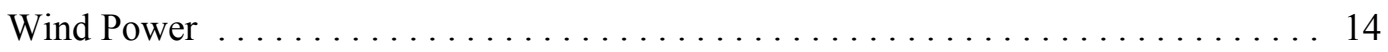

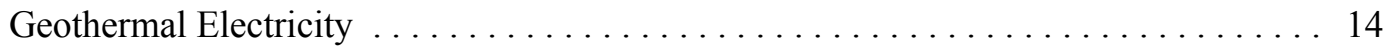

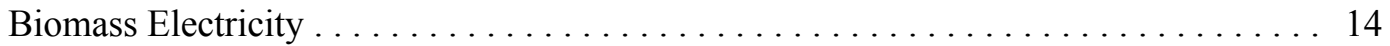

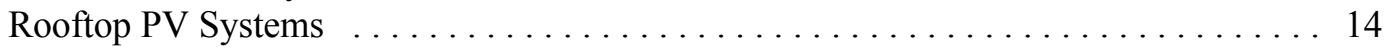

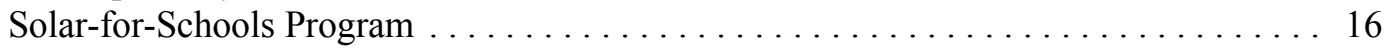

Preferences for Rate Basing versus Green Pricing $\ldots \ldots \ldots \ldots \ldots \ldots \ldots \ldots \ldots \ldots \ldots \ldots \ldots \ldots \ldots \ldots$ 
Appendix C: Data on Willingness to Pay for Power from Renewable Sources in

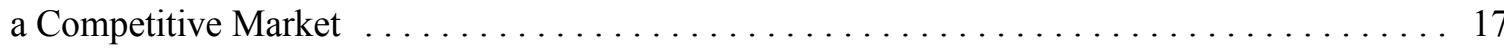

Appendix D: Data on Consumer Attitudes toward Utilities $\ldots \ldots \ldots \ldots \ldots \ldots \ldots \ldots \ldots \ldots \ldots$

\section{Tables}

Table A-1 Preferences among Energy Resources $\ldots \ldots \ldots \ldots \ldots \ldots \ldots \ldots \ldots \ldots \ldots$

Table A-2 Preferences among Fuel Sources for Use by Utility as One Source of Electricity $\ldots \ldots \ldots 8$

Table A-3 Favorability toward Various Renewables Options $\ldots \ldots \ldots \ldots \ldots \ldots \ldots \ldots \ldots \ldots$

Table B-1 Likelihood of Paying More in Monthly Bill to Support Energy Generated from

Renewable Resources . . . . . . . . . . . . . . . . . . . . . . . 10

Table B-2 Likelihood of PV System Purchase with Higher or the Same Monthly Electric Bill . . . . 10

Table B-3 Likelihood of Voluntarily Paying for Electricity from Renewable Sources . . . . . . . 10

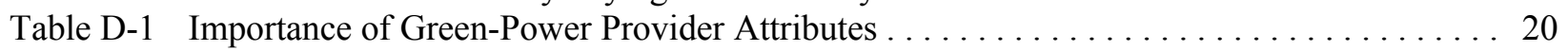

\section{Figures}

Figure 1 Aggregated Willingness-to-Pay Curve (Residential Customers) $\ldots \ldots \ldots \ldots \ldots \ldots \ldots$

Figure B-1 Incremental Bimonthly Amounts Commercial Customers Are Voluntarily Willing

to Pay for Electricity from Renewable Sources $\ldots \ldots \ldots \ldots \ldots \ldots \ldots \ldots \ldots \ldots$

Figure B-2 Incremental Bimonthly Amounts Respondents Are Voluntarily Willing

to Pay to Support New Renewable Energy . . . . . . . . . . . . . . . . . . . . . 12

Figure B-3 Incremental Monthly Amounts Respondents Are Voluntarily Willing

to Pay for Electricity from Renewable Sources . . . . . . . . . . . . . . . . . . 12

Figure B-4 Incremental Monthly Amounts Respondents Are Voluntarily Willing to Pay for Solar and Wind Power before and after Deliberation on Electricity Issues . . . . 13

Figure B-5 Incremental Monthly Amounts Respondents Are Voluntarily Willing to Pay for Electricity Generation from Renewables (Averaged Data from Three Surveys before and after Deliberation $\ldots \ldots \ldots \ldots \ldots \ldots \ldots \ldots \ldots \ldots$

Figure B-6 Incremental Monthly Amounts Respondents Are Voluntarily Willing

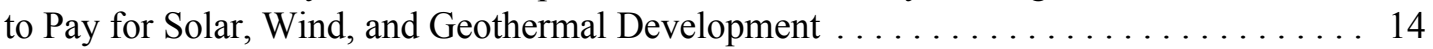

Figure B-7 Incremental Monthly Amounts Respondents Are Voluntarily Willing to Pay for Wind Power . . . . . . . . . . . . . . . . . . . . . . . . 14

Figure B-8 Incremental Monthly Amounts Respondents Are Voluntarily Willing

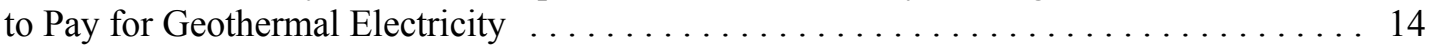

Figure B-9 Incremental Monthly Amounts Respondents Are Voluntarily Willing

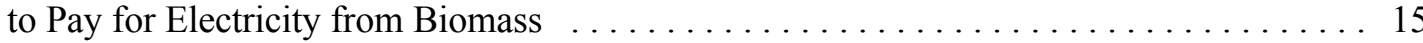

Figure B-10 Incremental Amounts Respondents Are Voluntarily Willing to Pay for Home-Based Rooftop PV System . . . . . . . . . . . . . . . . . . . . . . . . 15

Figure B-11 Incremental Monthly Amounts Respondents Are Voluntarily Willing to Pay on Electric Bills for a Rooftop PV System . . . . . . . . . . . . . . . 15

Figure B-12 Incremental Monthly Amounts Respondents Are Voluntarily Willing

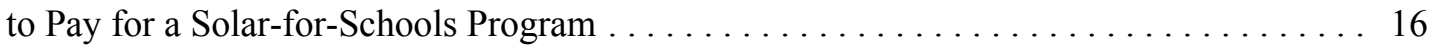

Figure C-1 Willingness to Pay for Electricity from Renewable Sources by Forgoing Different

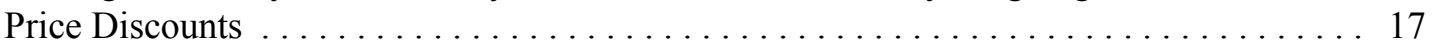

Figure C-2 Willingness to Subscribe to Product with Different Levels of Environmentally Friendly

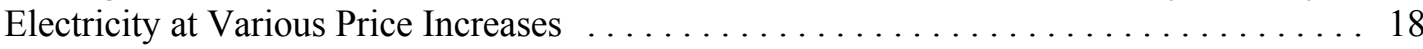




\section{Abstract}

As competition in the electric utility industry becomes more widespread, utilities are becoming concerned about actions they can take to help ensure the loyalty of their customers. National polls have, for 20 years, found majority preferences for renewable energy over other energy sources. This issue brief compiles and analyzes recent market research conducted by utility companies on customer interest in, and willingness to pay for, electricity from renewable sources. Increasingly, market research is documenting in utility service territories the same widespread preference for renewables that has been found in national polls for the past 20 years.

Findings in this review show that:

- Customers favor renewable sources of electricity but may know little about them. Percentages favorable toward renewables increase when customers are educated about options. Solar and wind are the most favored sources of electricity generation.

- Majorities of $52 \%$ to $95 \%$ of residential customers say they are willing to pay at least a modest amount more per month on their electric bills for power from renewable sources. Deliberative polls show that willingness to pay increases when customers are educated about utility energy options.
- Willingness to pay follows a predictable pattern with an average majority of $70 \%$ willing to pay at least $\$ 5$ per month more for electricity from renewable sources, $38 \%$ willing to pay at least $\$ 10$ per month more, and $21 \%$ willing to pay at least $\$ 15$ per month more. It is likely that any utility market survey asking residential customers about willingness to pay more for renewable energy will exhibit a similar pattern of results.

- A limited amount of data suggest that customers may be even more likely to pay more for electricity from renewable sources in a competitive market setting. That is, customers may respond in greater numbers when the choice is between forgoing rate decreases - as would be expected in competitive markets - than when faced with paying more, as is the case with utility greenpricing programs.

- Customers may view with favor and remain loyal to utilities that provide power from renewable sources. 


\section{Acknowledgments}

This study was sponsored by the Office of Power Technologies, Office of Energy Efficiency and Renewable Energy, U.S. Department of Energy (DOE). The author would like to thank the utility companies that provided studies to the National Renewable Energy Laboratory (NREL) collection of utility market research.

The author would also like to thank the following reviewers, who provided many helpful comments and suggestions: Joseph Galdo, DOE; Larry Goldstein, NREL; Blair Swezey, NREL; Bill Babiuch, NREL; Eldon Boes, NREL;
Timothy Coburn, Abilene Christian University; Nancy Collins, Q4 Associates; Ed Holt, Ed Holt and Associates; Rudd Mayer, LAW Fund; Terry Peterson, Electric Power Research Institute; John Reed, TECMrkt Works; Adam Serchuk, Renewable Energy Policy Project; Suzette Tucker-Welch, New Century Energy; and Ryan Wiser, Lawrence Berkeley National Laboratory. Timothy Coburn and David Lillie, User Interface Services, assisted in developing the willingness-to-pay curve. Special thanks are also expressed to Kyra Epstein for editorial assistance and Irene Medina and Kay Vernon for word-processing support. 


\section{Willingness to Pay for Electricity from Renewable Sources: A Review of Utility Market Research}

\section{Approach}

This issue brief compiles and analyzes recent market research conducted by utility companies on customer interest in and willingness to pay for electricity from renewable sources. The National Renewable Energy Laboratory (NREL) has obtained the results of market research studies on green pricing from several electric utility companies. To honor the proprietary nature of the data, identities of the utilities conducting the studies have not been provided. The data come from 14 different surveys conducted in 12 utility service territories in five Western/Southwestern states. Most of the data were collected in 1995 through 1997. In addition, the study incorporates results from a 1997 Electric Power Research Institute (EPRI) study (EPRI 1997).

The analysis focuses on the results from quantitative surveys rather than on focus group findings, since quantitative data collection was often built on focus group results and took the focus group findings further to enable generalizations about entire populations. Use of survey data makes the comparison of results among studies more straightforward.

In addition, the analysis was limited only to data from surveys that appeared to meet "best practice." Data were collected for utility companies by professional market research firms. The surveys used scientific procedures to sample utility customers, and results had estimated margins of error of $\pm 5 \%$ or better. In addition, only questions that were, in our opinion, of high quality, relatively objective, and unbiased were included. Because the questions themselves are considered proprietary, they are not included here.

The studies provided far more information than could be reviewed in this short paper; therefore, the analytical focus was limited to three topics of widespread interest to the utility industry. These were: (1) attitudes toward and knowledge of renewables, (2) customer interest in paying more for electricity from renewable sources (including stated willingness to pay more for electricity from renewable sources and preferences for paying for renewables in the rate base versus on a voluntary basis), and (3) consumer attitudes toward utility companies as suppliers of power from renewable sources. Of these three topics, most of the questions asked were about willingness to pay for electricity from renewable sources. For purposes of this synthesis, findings from questions on like topics, although not worded identically, are grouped together.

This paper presents a summary of key findings; detailed data are presented in the appendixes. The aggregation of utility market research data on willingness to pay is discussed. We also include some related findings from other recently reported market research.

\section{Key Findings}

Attitudes toward Renewables. Many surveys have documented, both nationally and locally, the longstanding preference among U.S. adults and electricity customers for renewable energy over other energy sources. Utility market surveys asking about attitudes toward renewables found the same strong preferences for renewable energy to produce electricity when compared with other energy sources, as has been documented in national poll data (Farhar 1993, 1996). Data detailing these findings are reported in Appendix A.

Knowledge of Renewables. Although consumers are favorable toward renewables, they may not know very much about renewable energy technologies. Utility findings on consumer favorability toward and knowledge of renewables are sparse. Most of the utility 
surveys reviewed did not query customers on their familiarity with renewable energy technologies. Customers, as a whole, are likely to be relatively unfamiliar with green power and are unlikely to know anyone who has participated in a green-power program. The few data that do exist suggest that participants in green-pricing programs tend to be more informed than customers in general, and that solar and wind are the best known renewable energy technologies. Appendix A presents the detailed findings.

\section{Stated Likelihood of Voluntarily Paying for Electricity from Renewable Sources. The data reviewed suggest that approximately half or more of respondents surveyed state that they are "somewhat likely" or "very likely" to voluntarily pay more for electricity from renewable sources when price is not mentioned. A sizable minority of samples $(\sim 45 \%)$ tend to indicate that they would be unlikely to voluntarily pay anything more for electricity from renewable sources, when the question is asked in this way. ${ }^{1}$ Two samples of commercial customers also expressed likelihood of paying a limited amount more for renewable power. Appendix B presents the data.}

\section{Stated Willingness to Pay More for Renewable Electricity by Residential Customers. Across the surveys reviewed, majorities of respondents say they are willing to pay at least a modest amount more per month on their electric bills for power from renewable}

\footnotetext{
${ }^{1}$ When survey questions take a form similar to: "If paying for renewable electricity were offered on a voluntary basis, how likely would you be to pay more money on a monthly basis to get some or all of your electricity from renewables?", and no dollar amount is given, sizable minorities tend to respond that they are unlikely to pay more. However, when survey questions take a form similar to: "How much more would you choose to pay on your electric bill each month to ensure that some or all of your electricity comes from renewable sources?", and dollar amounts are given-usually $\$ 1, \$ 2, \$ 3, \$ 5$, and so on - only about $25 \%$ of respondents indicate they are unwilling to pay anything more when they see the modest amounts involved.
}

sources. The sizes of these majorities range from $52 \%$ to $95 \%$ of total residential customer samples without exposure to special educational programs. Percentages increase when customers receive more information. Appendix B presents the detailed information.

\section{An Aggregated Residential Customer} Willingness-to-Pay Curve. The similarities in findings on willingness to pay (WTP) for electricity from renewable sources is striking, and a means was sought to describe this observed pattern. A best-fit curve was developed for a scatterplot of the averaged value of incremental amounts per month residential respondents stated that they are willing to pay for various forms of electricity from renewable sources (Figure 1). ${ }^{2}$ The curve is based only on responses from residential customers. It includes 95 data points from 12 survey questions. ${ }^{3}$

Figure 1 presents data on the percentages of survey respondents indicating they are willing to pay nothing more and those willing to pay increasing amounts more. As would be expected, the percentage of those willing to pay more drops off as the price increases. An average of $70 \%$ are likely to state

\footnotetext{
${ }^{2}$ The curve represents an exponential fit to the data. This "best-fit" curve (in terms of maximizing $\mathrm{R}^{2}$ ) was obtained using nonlinear regression with the Y-intercept set at $100 \%$. The scatter of response values around the average values depicted in the curve is most likely a function of variation in question wording, question placement, and the dollar values used in response categories.

${ }^{3}$ Data on WTP for grid-tied rooftop photovoltaic (PV) systems were omitted because the amounts involved are much higher than the amounts mentioned in most surveys on green-pricing programs. Bimonthly dollar amounts were halved to make them comparable to the monthly dollar amounts used in most questions. Only "pre" data from deliberative polls were included so that data would be comparable with that from random samples of utility customers. Also, some WTP questions were broad in nature and did not include questions on varying pricing structures.
} 
that they will pay at least $\$ 5$ per month more. An average of $38 \%$ of customers are likely to state they will pay at least $\$ 10$ more. An average of $21 \%$ are likely to state that they would pay $\$ 15$ per month more.

Although these figures represent an important market potential, they should not be construed as the proportion of residential customers who will actually sign up for a greenpower product offering at inception. In addition, this curve could change over time as the population gains more experience with greenpower programs.

Given the coverage of the research, it is likely that any utility market survey asking residential customers about WTP for power from renewable sources will obtain results similar to those represented by the curve. Development of a curve on actual participation in green-pricing programs must await the collection of systematic data on participation rates over time.

\section{Preferences for Rate Basing versus} Green Pricing. Virtually all questions in this review focused exclusively on a utility greenpricing option. The one question addressing customer preference for distributing the costs of new renewables development across the entire customer population showed that customers strongly preferred "rate basing." Detailed information is presented in Appendix B.

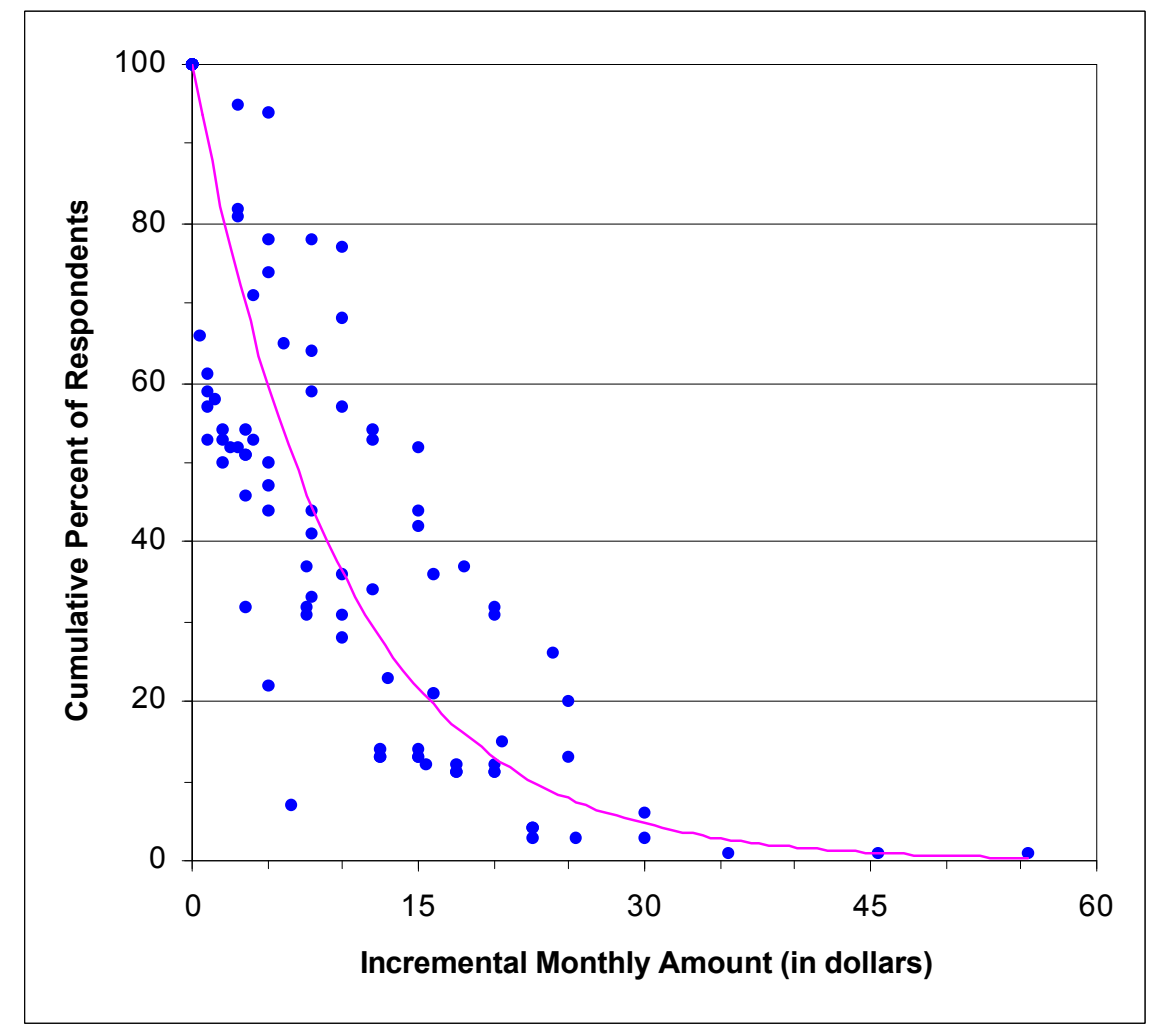

The equation for the curve is:

$$
\mathrm{Y}=100 \mathrm{e}^{-.104 * \mathrm{M}}
$$

where $\mathrm{Y}=$ cumulative percentage of respondents, and $\mathrm{M}=\$$ more per month. $\mathrm{R}^{2}=.76$

Figure 1. Aggregated Willingness-to-Pay Curve (Residential Customers) 


\section{Willingness to Pay for Power from} Renewables in Competitive Markets. Two questions asked utility customers about their willingness to forgo price decreases in competitive utility markets to pay for electricity from renewable sources. The few data available show that even higher majorities of customers may be willing to forgo price decreases to pay for environmentally friendly electricity than are willing to voluntarily pay more on their electric bills. Appendix $\mathrm{C}$ presents detailed data.

Attitudes toward Utilities. Most residential customers in these samples rate their utilities favorably. Majorities of utility customers want their utility companies to develop new renewable sources of electricity. Findings suggest that those most satisfied with their utility company are also most supportive of adding new renewables to the power mix. Also, participants in green-pricing programs are significantly more loyal to their utility company than are other customers. Detailed findings are presented in Appendix D.

\section{National Poll Data and Other Recent Market Research Findings}

Findings from the utility market research synthesized here are consistent with other reported research, including national poll data and company-specific market research. Some examples of these findings are briefly provided below.

\section{Attitudes toward and Knowledge of}

Renewables. In a review of market research on renewables and conservation in the Pacific Northwest, Ferguson (1999) found that strong majorities of electricity customers in the Northwest support renewable energy. Ferguson concluded that Northwest consumers view conservation and renewables as being environmentally important.

Consumers continue to select renewables over other energy sources in response to questions asking for their preferences among conventional and renewable energy options. For example, a 1998 poll of Colorado homeowners found that the electricity sources perceived as least environmentally threatening - solar and wind - are also the most preferred (Farhar and Coburn 1999a). In addition to their environmental benefits, solar and wind are preferred over other electricity sources for other positive attributes, such as safety, economic benefits, self-reliance, and diversity of the U.S. energy supply. Similar findings from a national sample are reported in Farhar and Houston (1996).

A 1997 Portland General Electric study found $41 \%$ of residential customers selecting solar over all other energy sources to meet the future electric needs of the region (cited in Ferguson 1999). These findings are consistent with results from national polls (Farhar 1996).

Combined results of surveys of probability samples from four Midwestern states showed that $90 \%$ of customers believe their utilities should use solar and $85 \%$ believe they should use wind to produce power (Tarnai and Moore 1998). Eighty-nine percent favored more use of renewables.

The 1998 Colorado homeowners survey found that although most respondents were favorable toward grid-tied photovoltaics (PV) (with 59\% giving it high favorability ratings), only $10 \%$ were familiar with it. Male respondents and those in higher-income households tended to be more familiar with gridtied PV than others, but they were still not very familiar (Farhar and Coburn 1999b).

\section{Willingness to Pay More for} Electricity from Renewable Sources. Farhar and Houston (1996) reported that $57 \%$ to $80 \%$ of national poll samples said they were willing to pay more for elecricity produced in a cleaner way or from sources less harmful to the environment. The 1998 survey of Colorado homeowners found that, when asked specific amounts, $76 \%$ of respondents indicated a willingness to pay at least $\$ 1$ per month more for electricity from renewable sources (Farhar and Coburn 1999a). 
Combined data from the poll of adults in four Midwestern states (Tarnai and Moore 1998) showed that $72 \%$ indicated they are "very willing" or "somewhat willing" to pay more for renewables. The modal amounts respondents were willing to pay were $\$ 5$ per month (30\%) and $\$ 10$ per month (28\%).

\section{Rate Basing versus Green Pricing.}

The Colorado homeowners survey shows broadbased support for renewables development even if it costs more (Farhar and Coburn 1999a). Homeowners prefer to see the costs of developing renewables shared broadly, either through federal subsidies for electricity generation using renewables or through modest increases in electric rates.

Ferguson (1999) reported that Seattle City Light customers preferred that the cost of renewables should be put in everyone's rates, rather than through green-pricing programs in which customers can choose to participate, a result also obtained by other Northwest utility market research.

The surveys of four midwestern states (Tarnai and Moore 1998) found that 30\% preferred that everyone's electric rates should be increased to pay for renewables, $29 \%$ preferred voluntary choice, and $19 \%$ preferred that the federal government pay additional costs. Twenty percent proposed some other way.

\section{Attitudes toward Utility Companies as Suppliers of Electricity from Renewable \\ Sources. Ferguson (1999) found that consumers consistently report they are more likely to identify with utilities that support environmentally sound management practices.}

The Colorado survey of homeowners found that widespread support exists for utilities to develop renewables as part of their electricitygenerating mix (Farhar and Coburn 1999a). Colorado utilities seem to have a relatively good reputation with their customers. Most homeowners want their utilities to do more to invest in the development of renewable sources of electricity.

\section{Conclusions}

- Customers favor renewable energy sources but tend to know very little about them.

- Utility market research studies show customer preference for renewable sources of electricity along with majority willingness to pay an incremental amount more for it. Across the studies examined, majorities of $52 \%$ to $95 \%$ said they were willing to pay at least a modest amount more per month on their electric bills for power from renewable sources. Deliberative polls show that customer WTP increases when customers are educated about utility energy options.

- Across all studies, customer WTP follows a predictable pattern. An average of $70 \%$ stated WTP at least \$5 per month for electricity from renewable sources. The percentages decline as the amount per month increases. An average of $38 \%$ of customers say they are willing to pay at least $\$ 10$ per month more, and $21 \%$ say they are willing to pay at least $\$ 15$ per month more for power from renewable sources. It is likely that any utility market survey asking residential electricity customers about WTP for renewables will exhibit a similar pattern of results.

- Proprietary utility market research findings track closely with findings from similar questions from national polls and market research in the public domain.

- A limited amount of data show that customers are just as likely to pay more for renewable energy in a competitive market setting. In fact, customers may respond in greater numbers when the choice is between forgoing rate decreases in order to receive renewable energy in competitive markets than when faced with paying more for this option, as is the case in utility green-pricing programs. 
- Although most studies focused on residential customers, there is limited evidence that some business customers will pay more for green power. These data, coupled with actual market experience with businesses voluntarily choosing green power options - such as Toyota, Patagonia, and the New Belgium Brewing Company_-suggest that business customers could be an important market segment for renewables. Business customers might be interested in knowing about the extent of interest in electricity from renewable sources among residential customers, because this interest could translate into consumer approval for businesses that purchase electricity from renewable sources.
- Although almost all of the surveys focused exclusively on a utility green-pricing type of option, the fact that large majorities of respondents are willing to pay at least a small, incremental amount for renewable energy suggests a potential willingness to accept slightly higher rates in order to capture the public benefits of greater renewable energy use.

- Customer attitudes are more favorable toward utilities that include renewables in their electricity generation mix. However, the evidence is insufficient to determine whether customers who trust their utilities more are more willing than others to sign up for green-power programs. 


\section{References}

Note: Utility studies are not identified because of the proprietary nature of the questions and findings.

Electric Power Research Institute (EPRI). 1997. Green Power Guidelines, Volume 1: Assessing Residential Market Segments. TR-109192-V1. Palo Alto, CA: Electric Power Research Institute.

Farhar, Barbara C. 1993. Trends in Public Perceptions and Preferences on Energy and Environmental Policy. NREL/TP-461-4857. Golden, CO: National Renewable Energy Laboratory. February. 376 pp.

Farhar, Barbara C. 1996. Energy and the Environment: The Public View. REPP Issue Brief, No. 3. College Park, MD: University of Maryland. 20 pp. http://www.repp.org.

Farhar, Barbara C. and Timothy C. Coburn. 1999a. Colorado Homeowner Preferences on Energy and Environmental Policy. NREL/TP-550-25285. Golden, CO: National Renewable Energy Laboratory. June. $45 \mathrm{pp}$.

Farhar, Barbara C. and Timothy C. Coburn. Forthcoming 1999b. A Market Assessment of Residential Grid-Tied PV Systems in Colorado. NREL/TP-25283. Golden, CO: National Renewable Energy Laboratory. In Press.

Farhar, Barbara C. and Ashley H. Houston. 1996. Willingness to Pay for Electricity from Renewable Energy. NREL/TP-460-21216. Golden, CO: National Renewable Energy Laboratory. September. $26 \mathrm{pp}$.

Ferguson, Edward G. 1999. "Renewable Resources and Conservation: What Consumers Want." Portland, OR: Bonneville Power Administration. 35 pp.

Tarnai, John and Danna L. Moore. 1998. "Regional Capability Building-Utility Restructuring Survey." Data Report 98-40, Social and Economic Sciences Research Center. Pullman, WA: Washington State University. November. 


\section{Appendix A: Data on Attitudes toward and Knowledge of Renewables}

\section{Attitudes toward Renewables}

Utility market surveys asking about attitudes toward renewables found the same strong preferences for renewable energy to produce electricity when compared with other energy sources, as has been documented in national poll data (Farhar 1993, 1996).

Table A-1 shows the results from a question asking customers about their favorability or opposition toward various energy resources, assuming that they had a choice as to the source of their electrical energy.

Another question resulted in a similar pattern of preferences when it asked whether residential and commercial customers want their utility to use a variety of energy sources.

Customers strongly support their utility's use of new renewables, defined as electricity generated by solar, wind, geothermal, and landfill gas sources. Of residential customers, $88 \%$ say their utility should include new renewables as one of their sources of electricity. Support for hydropower is similarly high. A majority supports the use of natural gas to generate electricity, while fewer support nuclear power and coal. Table A-2 shows the results.
Table A-2. Preferences among Fuel Sources for Use by Utility as One Source of Electricity

\begin{tabular}{|l|c|c|}
\hline & $\begin{array}{c}\text { Residential } \\
\%\end{array}$ & $\begin{array}{c}\text { Commercial } \\
\%\end{array}$ \\
\hline New renewables & 88 & 89 \\
\hline Hydropower & 85 & 91 \\
\hline Natural gas & 55 & 64 \\
\hline Nuclear & 39 & 52 \\
\hline Coal & 14 & 22 \\
\hline
\end{tabular}

More evidence for this pattern of preferring renewable sources came from a question asking customers about their preferences for purchasing electricity from coal, nuclear, natural gas, or wind and solar. Findings show that $41 \%$ say they would choose electricity from wind and solar, 35\% from natural gas, 9\% from nuclear energy, and 5\% from coal; $10 \%$ don't know.

Table A-1. Preferences among Energy Resources

\begin{tabular}{|l|c|c|c|c|}
\hline Energy Resource & $\begin{array}{c}\text { Somewhat or } \\
\text { strongly favor } \\
\%\end{array}$ & $\begin{array}{c}\text { Somewhat or } \\
\text { strongly oppose } \\
\%\end{array}$ & $\begin{array}{c}\text { Don't } \\
\text { know } \\
\%\end{array}$ & Totals \\
\hline Solar & 93 & 5 & 2 & 100 \\
\hline Wind & 91 & 9 & -- & 100 \\
\hline Natural gas & 83 & 11 & 6 & 100 \\
\hline Geothermal & 71 & 13 & 16 & 100 \\
\hline Landfill gas & 64 & 18 & 18 & 100 \\
\hline Forest waste & 59 & 29 & 12 & 100 \\
\hline Nuclear & 31 & 63 & 6 & 100 \\
\hline Coal & 24 & 69 & 7 & 100 \\
\hline
\end{tabular}


Another question asked respondents about favorability toward specific renewable energy sources and also about their top three choices for their utility company to develop. Overwhelming majorities choose wind, PV on homes, geothermal, and PV on schools, and a majority also choose biomass energy. Among the top three choices for development, wind is preferred by two-thirds, followed by PV on homes (64\%), and geothermal (63\%). PV on public buildings is preferred by a $58 \%$ majority. Biomass is selected as a top three choice by $26 \%$. Table A-3 shows the findings.

Table A-3. Favorability toward Various Renewables Options

\begin{tabular}{|l|c|c|}
\hline $\begin{array}{l}\text { Renewable } \\
\text { resource }\end{array}$ & $\begin{array}{c}\text { Percent } \\
\text { "very } \\
\text { favorable" }\end{array}$ & $\begin{array}{c}\text { Percent choosing } \\
\text { in top 3 preferred } \\
\text { renewable } \\
\text { energy choices }\end{array}$ \\
\hline $\begin{array}{l}\text { PV on public } \\
\text { building }\end{array}$ & 69 & 58 \\
\hline Geothermal & 64 & 63 \\
\hline Wind & 61 & 69 \\
\hline PV on homes & 60 & 64 \\
\hline Biomass & 32 & 26 \\
\hline
\end{tabular}

Results from another question show favorability toward the idea of utility investment in renewable energy among the customer groups surveyed. On a 1-10 scale, where 1 is low and 10 is high favorability, the mean score for participants in a green-power program is 9.1 and, for all other customers, 6.3.

Findings show that, among customer groups surveyed, most agree that their utility company should provide power from sources that minimize negative environmental impacts (mean scores ranging from 7.7 to 9.2 on a 1-10 scale). Similarly, most agree that the utility should protect the environment as much as possible while producing and distributing power (mean scores ranging from 8.2 to 8.6 on a $1-10$ scale).

\section{Knowledge of Renewables}

Only a few of the utility surveys reviewed included questions on awareness and knowledge of renewables. One question showed that commercial customers are slightly more aware of electricity from renewable energy sources than residential customers. The most well-known new renewable energy sources are solar and wind power, of which most customers are aware. Landfill gas and geothermal sources have the lowest awareness levels (between half and three-quarters aware). Not surprisingly, almost all commercial and residential customers have heard of hydropower. Another question produced results showing that, although $84 \%$ have heard of using solar panels to produce electricity, lack of knowledge is commonly cited as a reason for not installing them.

Another question was asked of a sample of subscribers to a green-power program, interested nonsubscribers (those who had inquired about the program, but did not subscribe), and other utility customers. Threequarters of subscribers, $53 \%$ of interested nonsubscribers, and $37 \%$ of other customers say they are familiar with the term "green energy." Despite the program having been in existence for $1 \frac{1}{2}$ years, $21 \%$ of subscribers, $45 \%$ of interested nonsubscribers, and $61 \%$ of other customers are not familiar with the term "green energy." This particular survey found that knowledge about wind power and green energy is significantly greater among program subscribers than among the other two groups. 


\section{Appendix B: Data on Customer Interest in Paying More for Electricity from Renewable Sources}

\section{Stated Likelihood of Paying More for Renewables}

Many residential and commercial customers respond that they are likely to pay more for renewables. In one study, $54 \%$ of residential customers say they are "very likely" or "somewhat likely" to pay more on their monthly electric bill for electricity from renewable sources; $45 \%$ say they are unlikely to do so (Table B-1).

Table B-1. Likelihood of Paying More in Monthly Bill to Support Energy Generated from Renewable Resources

\begin{tabular}{|l|c|}
\hline Response & $\%$ \\
\hline Very likely & 13 \\
\hline Somewhat likely & 41 \\
\hline Not likely & 45 \\
\hline Unsure & 1 \\
\hline Total & 100 \\
\hline
\end{tabular}

Another question asked about purchasing a residential, grid-tied PV system. When asked directly how likely they would be to purchase a PV system if the cost of the loan payment plus their new, reduced electric bill combined would remain the same, $21 \%$ of customers say they are "very likely" to purchase a PV system, 42\% say they are "somewhat likely," 33\% say they are "not likely" to do so, and $4 \%$ don't know.

In response to a different question, $38 \%$ say they would be likely to purchase a PV system if their monthly bill were higher than it currently is. Table B-2 shows the responses.

Results from another question asked of both residential and commercial customers indicate that the likelihood of voluntarily paying
Table B-2. Likelihood of PV System Purchase
with Higher or the Same
Monthly Electric Bill

\begin{tabular}{|l|c|}
\hline Response & $\%$ \\
\hline Yes & 38 \\
\hline No, but would if bill remained the same & 32 \\
\hline No, but would purchase at lower price & 12 \\
\hline Would not purchase at all & 6 \\
\hline Unsure & 12 \\
\hline Total & 100 \\
\hline
\end{tabular}

more for electricity from renewable sources is relatively high. Two-thirds of residential customers and $61 \%$ of commercial customers say they are at least somewhat likely to pay more for electricity from renewable energy sources on a voluntary basis. Table B-3 shows the stated likelihood among both residential and commercial customers.

In response to another question, both residential and commercial customers $(62 \%$ and $65 \%$, respectively) agree that using new renewable energy is "the responsible thing to do for the future, even if it costs more now." Far fewer residential and commercial customers

Table B-3. Likelihood of Voluntarily Paying More for Electricity from Renewable Sources

\begin{tabular}{|c|c|c|}
\hline Response & $\begin{array}{c}\text { Residential } \\
\%\end{array}$ & $\underset{\%}{\text { Commercial }}$ \\
\hline Very likely & 16 & 21 \\
\hline Somewhat likely & 51 & 40 \\
\hline Not very likely & 17 & 21 \\
\hline Not at all likely & 14 & 14 \\
\hline Don't know & 3 & 3 \\
\hline Total & $101^{a}$ & $99^{a}$ \\
\hline
\end{tabular}


( $29 \%$ and $27 \%$, respectively) think that maintaining current rates as long as possible is important, even if it means using fossil fuels.

Although commercial and industrial customers were rarely included in the utility market research reviewed, available data provide modest evidence that at least some of these customers might be interested in power from renewable sources. In one study, a majority $(53 \%)$ of industrial respondents say they are unwilling to pay a higher price for "greener" electricity resources. ${ }^{1}$ However, $41 \%$ say they are willing to pay $5 \%$ or more for greener electricity resources, and $6 \%$ say they are willing to pay more than $10 \%$ more.

A question from another study showed that $62 \%$ of commercial customers are willing to pay at least $\$ 1$ more every other month for electricity from renewable sources; $57 \%$ are willing to pay at least $\$ 3$ more; and $52 \%$ are willing to pay at least $\$ 5$ more every other month. However, only $11 \%$ are willing to pay more than $\$ 10$ more every other month. Thirtyeight percent of respondents to this question are unwilling to pay anything more (Figure B-1).

Although not numerous, these results - along with anecdotal evidence about large businesses such as Toyota, Patagonia, and New Belgium Brewing Company selecting a green-power option in a competitive marketsuggest that commercial, and possibly industrial, customers are worth further investigation as a potential green-power market segment. In addition, these customers would probably be interested in information on the extent of interest in electricity from renewable sources among residential customers. This interest could

\footnotetext{
${ }^{1}$ The survey included respondents from 13 different SIC codes, including printing and publishing, electronic and other equipment, and other manufacturing. However, only 17 respondents answered this question on renewable sources of electricity.
}

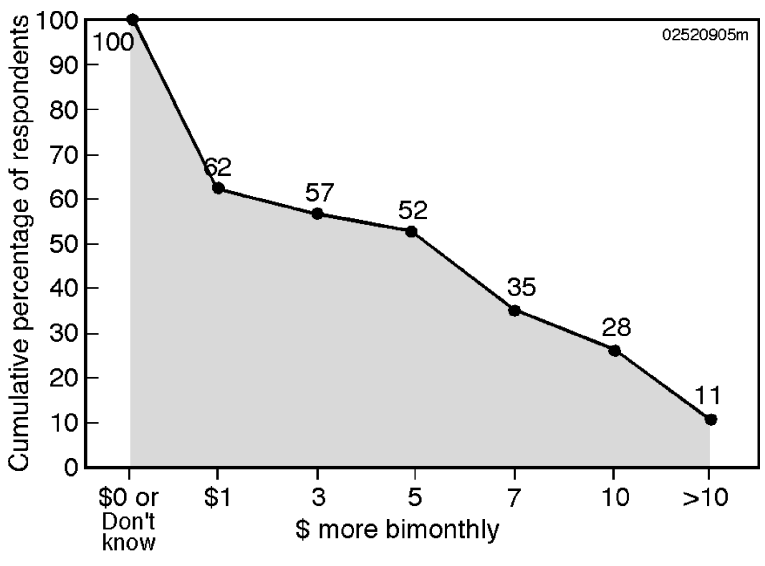

\section{Figure B-1. Incremental Bimonthly Amounts Commercial Customers Are Voluntarily Willing to Pay for Electricity from Renewable Sources $^{2,3}$}

translate into a higher public approval of companies purchasing power from renewable energy sources.

${ }^{2}$ There was insufficient information to determine the percentage responding $\$ 0$ and the percentage responding "Don't know."

${ }^{3}$ Where data on WTP for electricity from renewable sources are presented, the percentages of respondents willing to pay higher amounts is added to the percentage willing to pay lower amounts to show a cumulative percentage of respondents willing to pay at least a stated amount. This is based on the assumption that those willing to pay a higher amount—say, \$25 a month more-would be willing to pay lower amounts - say, $\$ 10$ a month more-for power from renewable energy sources.

Figure B-1 and many of the charts that follow display WTP responses as cumulative percentages. For example, in Figure B-1, 62\% of respondents indicate that they would be willing to pay at least $\$ 1$ bimonthly for electricity from renewable sources. The cumulative curve is drawn to $100 \%$ at $0 \%$ to indicate that, in this case, some additional number of respondents that answered "zero" may have, if asked, been willing pay some amount between zero and $\$ 1$. 


\section{Stated Willingness to Pay More for Electricity from Renewable Sources by Residential Customers}

No matter how the question was phrased, a large percentage of residential customers - in all surveys a majority - stated that they are willing to pay at least something more on their electricity bills for electricity from renewable sources. Among most of the surveys analyzed here, majorities of respondents are willing to pay at least $\$ 5$ a month more for power from renewable energy sources.

In response to one question, $57 \%$ say they are willing to pay $5 \%$ or more for environmentally sound electricity, and $15 \%$ say they are willing to pay $10 \%$ or more. Stated WTP varied by income but did not vary by electricity consumption. If a rebate were offered, $70 \%$ say they would be willing to pay for more environmentally friendly electricity sources.

Another result shows that respondents tend to support the option of paying "green rates." On the whole, respondents say they would "somewhat favor" paying a premium of $5 \%$ for electricity generated from renewable resources. On a four-point scale, where 1 represents "strongly favor" and 4 "strongly oppose," the mean value is 1.83 . The average favorability toward paying a $20 \%$ premium is in the ambivalent range $($ mean $=2.36)$.

Response to another question shows that two-thirds of residential customers state that they are willing to pay at least $\$ 1$ more every other month for electricity from renewable sources; $58 \%$ are willing to pay $\$ 3$ every other month; and $52 \%$ are willing to pay at least $\$ 5$ every other month. Seven percent said they are willing to pay more than $\$ 10$ more every two months for electricity from renewable energy sources (Figure B-2).

Another question asked respondents whether they favor inceasing their electric bill by \$1 a month so that solar and wind power would be produced in their area. Three-quarters of respondents say they favor such an increase; $21 \%$ oppose it; $2 \%$ are mixed; and $2 \%$ don't know.

Response to a different question shows that $95 \%$ of individuals in the sample say they are willing to pay at least $\$ 3$ more per month on their electric bills for electricity from renewable sources (Figure B-3).

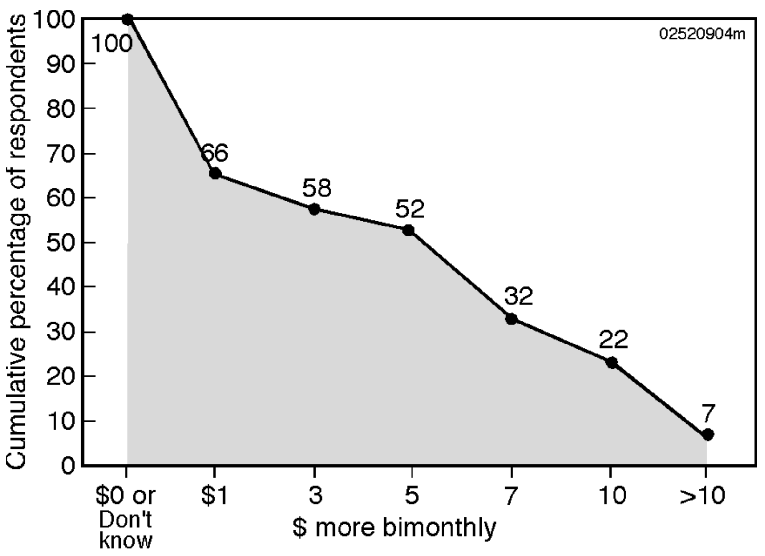

Figure B-2. Incremental Bimonthly Amounts Respondents Are Voluntarily Willing to Pay to Support New Renewable Energy ${ }^{4}$

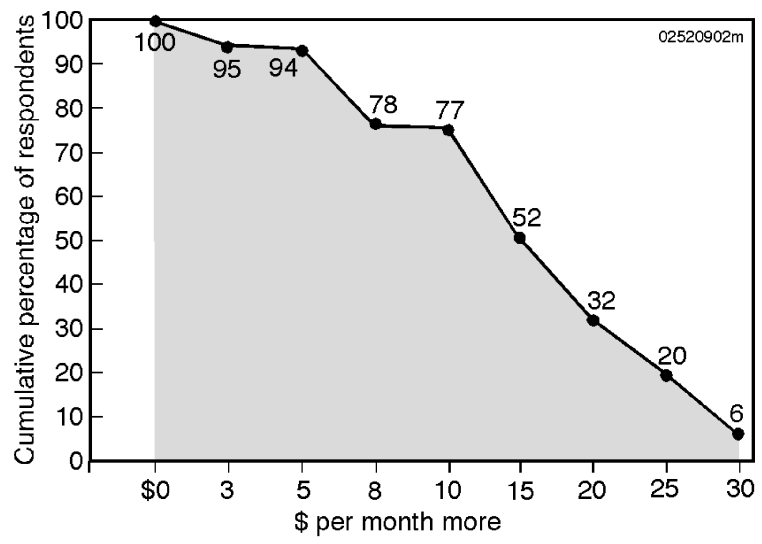

Figure B-3. Incremental Monthly Amounts Respondents Are Voluntarily Willing to Pay for Electricity from Renewable Sources

${ }^{4}$ There was insufficient information to determine the percentage responding $\$ 0$ and the percentage responding "Don’t know." 
Three surveys looked at customer WTP through an innovative polling technique called "deliberative polling." Using this technique, a sample of electricity customers comes together and completes a questionnaire prior to spending a weekend discussing electricity issues. The customers receive relatively unbiased presentations by energy experts and participate in facilitated discussions, termed a "deliberation." The sample then completes an identical questionnaire at the end of the weekend.

A question in one such deliberative poll questionnaire asked about WTP for electricity generation using wind and solar power. Prior to participating in deliberation, $52 \%$ of respondents said they would be willing to pay $\$ 1-\$ 5$ more per month for solar and wind power. After the deliberation, $77 \%$ said they would be willing to pay that amount. The percentage unwilling to pay anything dropped from $38 \%$ prior to deliberation to $18 \%$ afterwards. The percentage of respondents willing to pay more than $\$ 20$ a month more did not appear to change as a result of the deliberation. Clearly, exposure to more information about electricity issues increased participants' WTP modest amounts for power from renewable energy sources (Figure B-4).

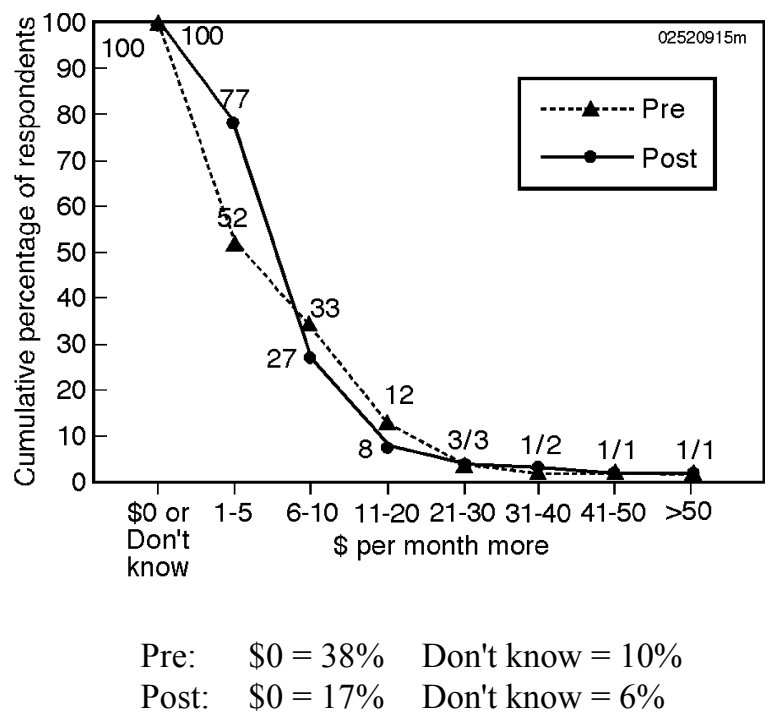

Figure B-4. Incremental Monthly Amounts Respondents Are Voluntarily Willing to Pay for Solar and Wind Power before and after Deliberation on Electricity Issues
Similar questions were asked in other deliberative polls, each of which used the same data collection instrument. On average, prior to deliberation, $56 \%$ of the combined customer samples say that they would pay at least $\$ 1$ a month more for electricity generation using technologies such as wind and solar, and approximately one-third say that they would pay at least $\$ 10$ a month more. After deliberation, the percentage willing to pay at least $\$ 1$ a month more increased to $85 \%$, while the percentage willing to pay at least $\$ 10$ a month more remained at almost one-third. (Figure B-5 shows the averaged percentages for the three surveys.)

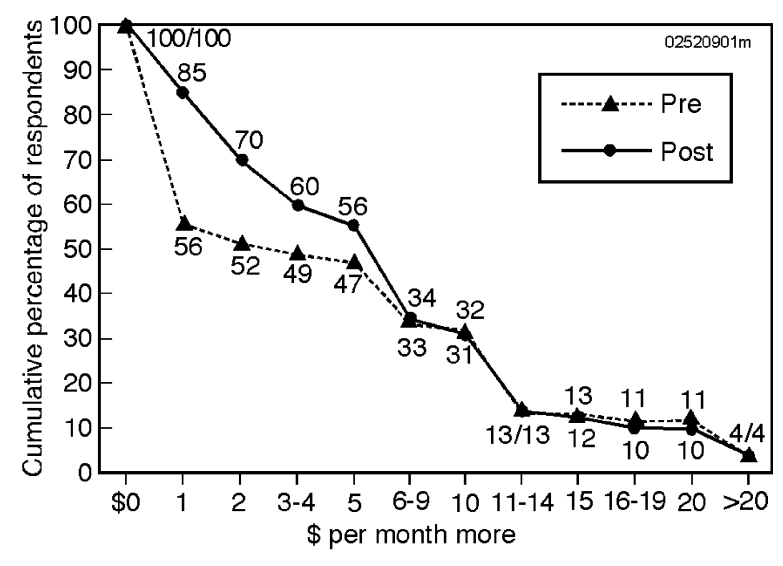

Figure B-5. Incremental Monthly Amounts Respondents Are Voluntarily Willing to Pay for Electricity Generation from Renewables (Averaged Data from Three Surveys before and after Deliberation)

\section{Specific Renewable Sources}

For specific renewable resources, responses follow a pattern similar to that generated from electricity from renewable energy sources in general. In response to one question, $61 \%$ of respondents say they are willing to pay up to $\$ 2$ per month more for solar, wind, and geothermal development; $54 \%$ say they would pay from $\$ 2$ to $\$ 5$ per month more; and 15\% say they would pay from $\$ 15$ to $\$ 25$ per month more. Twenty-eight percent say they are unwilling to pay more (Figure B-6). These results represent the general trend pertaining to all renewables. 


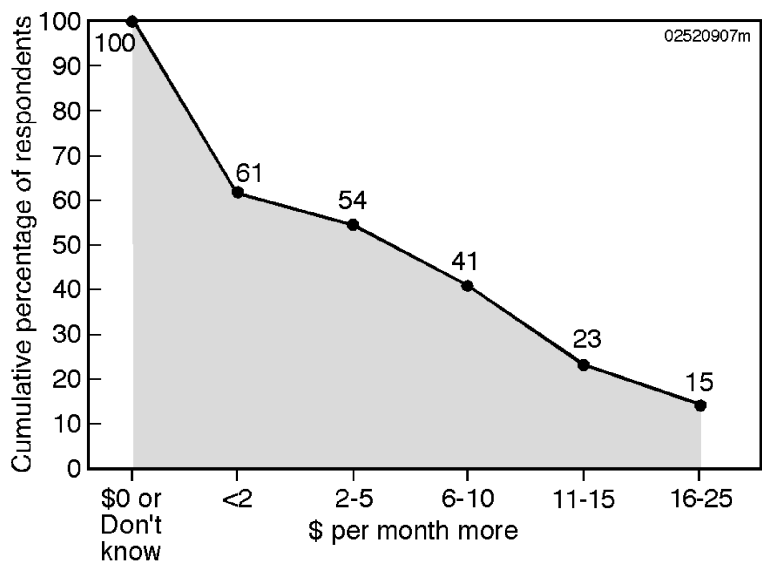

$\$ 0=28 \%$; Don't know $=11 \%$

Figure B-6. Incremental Monthly Amounts Respondents Are Voluntarily Willing to Pay for Solar, Wind, and Geothermal Development

Wind Power. Another question asked specifically about wind power. Sixty-five percent say they are willing to pay at least $\$ 6$ per month more, and $26 \%$ say they would pay more than $\$ 18$ a month more on their electricity bills for wind power (Figure B-7).

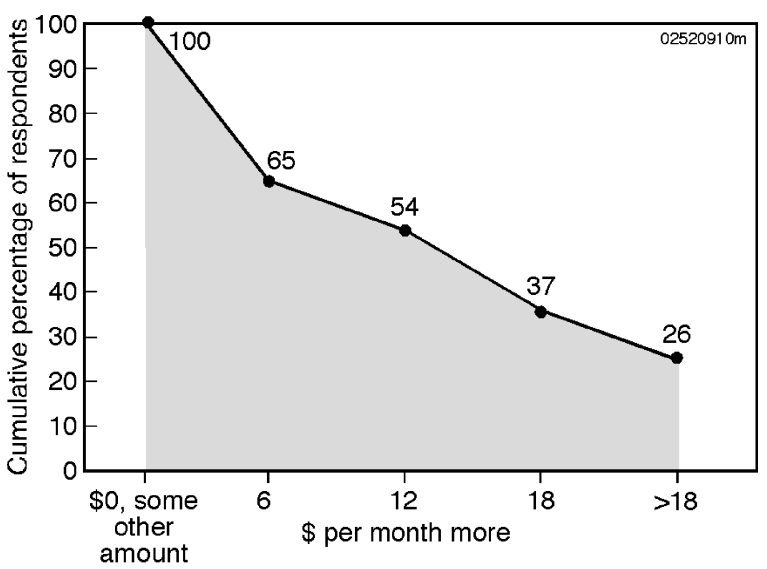

$\$ 0=31 \%$; Some other amount $=4 \%$

Figure B-7. Incremental Monthly Amounts Respondents Are Voluntarily Willing to Pay for Wind Power
Geothermal Electricity. Another question examined WTP for geothermal electricity.

Although $27 \%$ are unwilling to pay anything more, $71 \%$ say they are willing to pay at least $\$ 4$ a month more for geothermal electricity. Thirty-six percent are willing to pay more than $\$ 12$ a month more (Figure B-8).

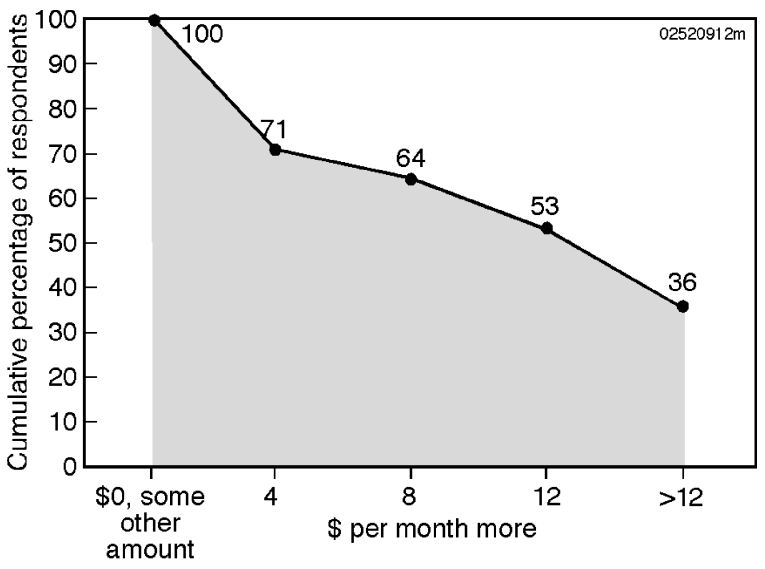

$\$ 0=27 \%$; Some other amount $=2 \%$

Figure B-8. Incremental Monthly Amounts Respondents Are Voluntarily Willing to Pay for Geothermal Electricity

Biomass Electricity. Another question examined WTP for biomass electricity. A majority of 53\% are willing to pay at least $\$ 4$ per month for electricity from biomass; $21 \%$ say they would pay more than $\$ 12$ a month more.

However, $45 \%$ say they are unwilling to pay anything more for biomass electricity, the highest percentage unwilling to pay among the surveys in this body of findings (Figure B-9).

Rooftop PV Systems. One question asked customers about WTP for a PV system at their home that they would own and that would reduce the amount of purchased power. Nearly $60 \%$ of respondents say they would be willing to pay at least \$25 per month for such a PV system; $38 \%$ say they would be willing to pay at least $\$ 50$ more; and $15 \%$ say they would be willing to pay at least $\$ 100$ a month more for a PV system at their homes (Figure B-10). 
at their homes (Figure B-10).

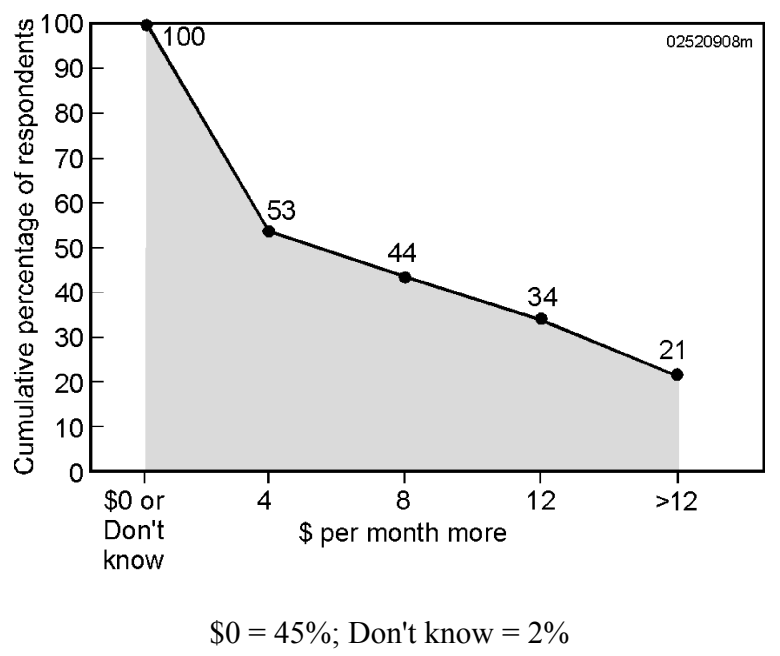

Figure B-9. Incremental Monthly Amounts Respondents Are Voluntarily Willing to Pay for Electricity from Biomass

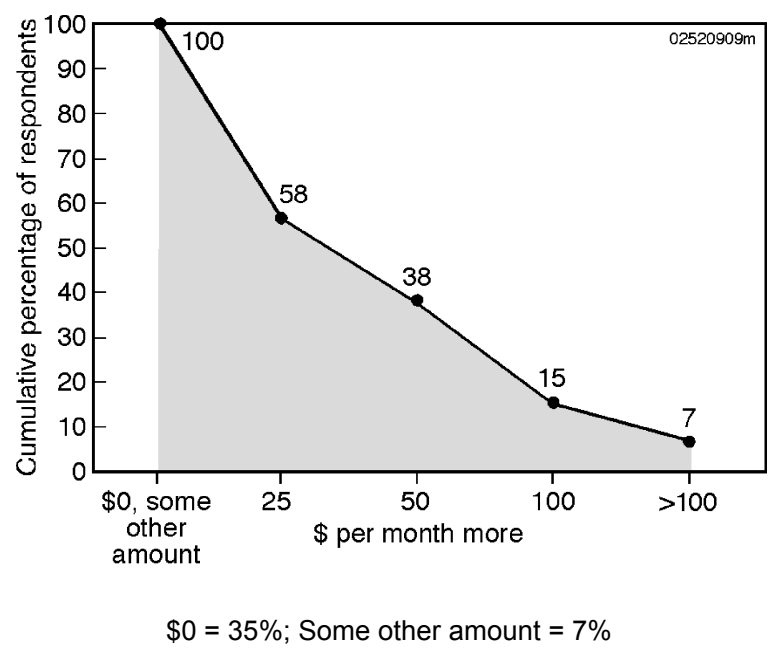

Figure B-10. Incremental Monthly Amounts Respondents Are Voluntarily Willing to Pay for Home-Based Rooftop PV System

In response to another question, respondents indicate a preference for rooftop PV systems that supply all of their electricity needs. Of those answering a question about whether they prefer a system supplying $50 \%$ or $100 \%$ of their electricity needs, $53 \%$ say they prefer the larger system and $26 \%$ say they prefer the smaller one; $21 \%$ don't know.
Regarding financing for the PV system, $46 \%$ say they prefer a long-term loan, $36 \%$ a short-term loan, and $18 \%$ are unsure.

Survey data were also collected from a general residential customer sample, and using the same instrument, from existing contributors to a green-pricing program, asking how much respondents would be willing to pay in a combined electric bill for a PV system installed on their roof that they would own. Most respondents in the general sample (82\%) are willing to pay as much as $\$ 3$ per month more for such a system, although it was not possible to discern how many people said "nothing more" because the data were not shown separately for that response. Eighty-two percent say they are willing to pay at least $\$ 3$ a month more for a PV system. Nearly one-third say they would be willing to pay $\$ 20$ per month more, and $13 \%$ say they are willing to pay $\$ 25$ per month more. Participants in a green-pricing program are likely to indicate even higher amounts, with $93 \%$ stating they are willing to pay at least $\$ 3$ more on their electric bill for a rooftop PV system they would own (Figure B-11).

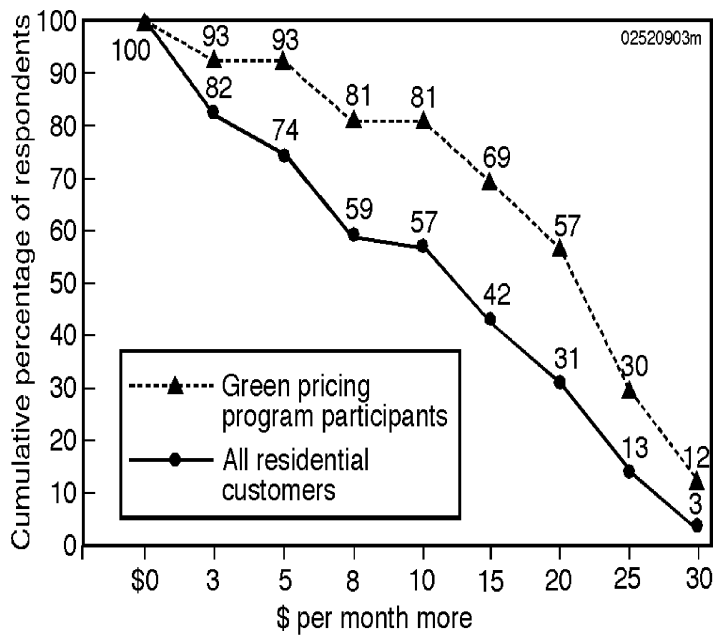

Figure B-11. Incremental Monthly Amounts Respondents Are Voluntarily Willing to Pay on Electric Bills for a Rooftop PV System 
Solar-for-Schools Program. A survey question measured WTP for a PV power system at a local school. A sizable majority $(81 \%)$ of utility customers in the sample say they are willing to pay at least $\$ 3$ per month more for a PV-for-schools program; 78\% say they are willing to pay at least $\$ 5$ per month more; $68 \%$ say they would pay at least $\$ 10$ per month more; and $44 \%$ say they would pay even more (Figure B-12).

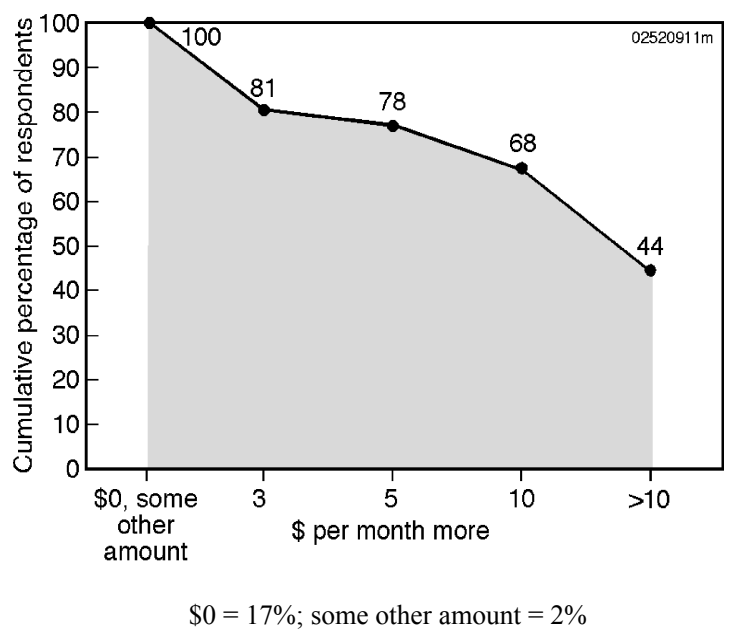

Figure B-12. Incremental Monthly Amounts Respondents Are Voluntarily Willing to Pay for a Solar-for-Schools Program

\section{Preferences for Rate Basing versus Green Pricing}

Only one question addressed the ratebasing versus green-pricing issue. The results showed strong support for spreading the costs of new renewables across the entire customer base. When given a choice, respondents asked this question agreed, by nearly four to one, that all households and businesses that can afford it should help pay for renewable power, as opposed to only voluntary purchasers. Seventy-four percent of the respondents in the residential sample and $80 \%$ of the commercial customer sample favored spreading the cost over the rate base. All the other questions included in this review focused exclusively on a utility greenpricing option. 


\section{Appendix C: Data on Willingness to Pay for Power from Renewable Sources in a Competitive Market}

Strong majorities of respondents nationwide also say that they are willing to choose electricity from renewable sources if their electric bills remain the same (EPRI 1997). Another way of measuring WTP is to ask customers to choose between two offers for electric service, one comparable to what customers are receiving already except that it is $5 \%, 10 \%$, and $15 \%$ lower in price, and one that ensures a supply of power from renewable sources at the price they are currently paying (EPRI 1997). In these scenarios, customers would be forgoing rate decreases to choose electricity from renewable energy sources.

Eighty-four percent of respondents nationwide say they would be willing to forgo a $5 \%$ discount in electricity prices to select power from renewable sources. Three-quarters (76\%) say they would be willing to forgo a $10 \%$ discount in order to select electricity from renewable sources, and $71 \%$ say they would be willing to forgo a $15 \%$ discount to purchase electricity from renewable sources (Figure C-1). These figures are higher than the usual range of WTP for power from renewable sources. This method may represent a less "painful" way of choosing power from renewable sources by allowing customers to opt for a slightly lower bill than they otherwise would have. This pattern of response may be more representative of a competitive market situation.

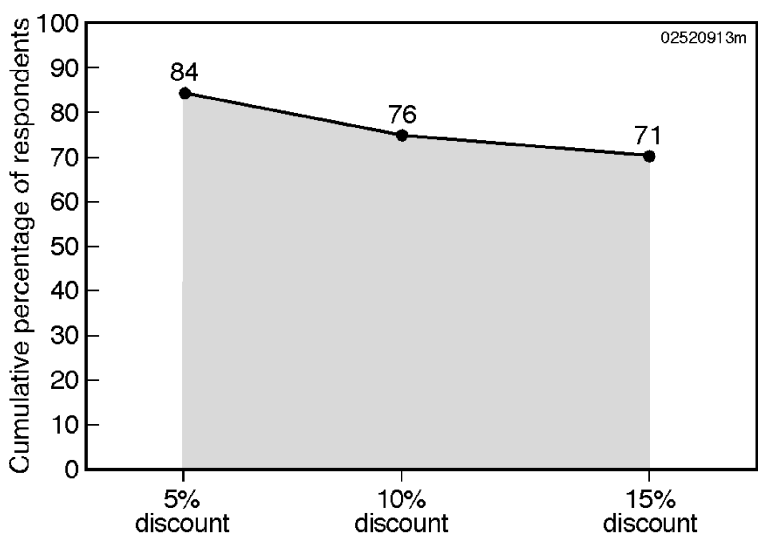

Figure C-1. Willingness to Pay for Electricity from Renewable Sources by Forgoing Different Price Discounts

Customers were asked about their interest in subscribing to different mixes (from $10 \%$ to $100 \%$ ) of "environmentally friendly" electricity. Interest was assessed for different levels of power from renewable sources at price increases ranging from $5 \%$ to $25 \%$. More than three-quarters of respondents say they are willing to pay at least a $5 \%$ premium to obtain all of their electricity from green sources, while one-third say they would pay a $25 \%$ increment. The pattern of responses, illustrated in Figure C-2, bears a similarity to the WTP curves discussed in the previous section. 


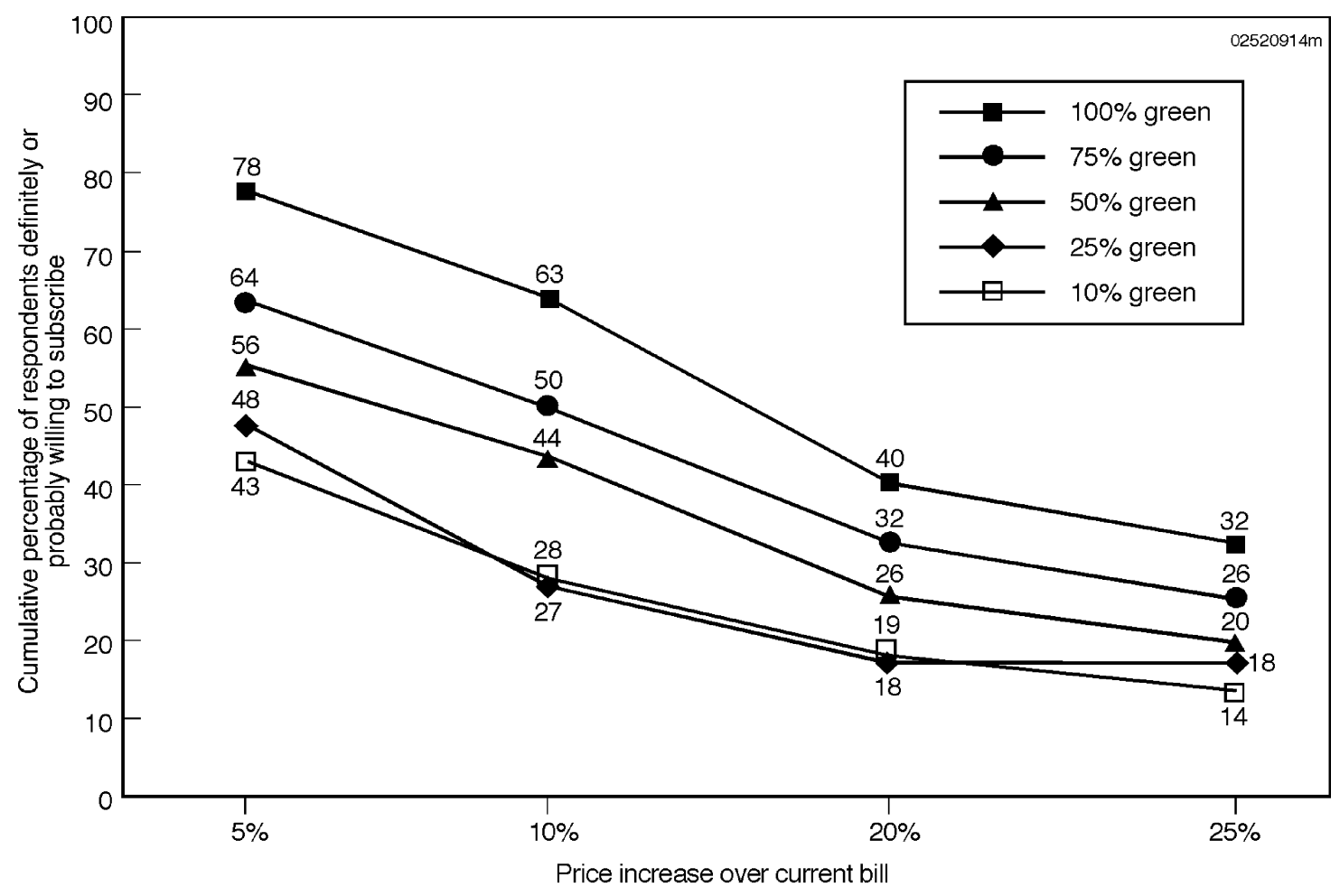

Figure C-2. Willingness to Subscribe to Product with Different Levels of Environmentally Friendly Electricity at Various Price Increases 


\section{Appendix D: Data on Consumer Attitudes toward Utilities}

A few of the surveys explored customers' attitudes toward utilities relative to the use of renewables to generate electricity. Although they do not constitute a strong pattern, the findings suggest that customers will look more favorably upon, and would be willing to purchase electricity from, a utility providing power from renewable sources.

Responses to one survey question showed that almost everyone wants the utility to develop new renewables to avoid resource depletion (93\%) and because it would be good for the environment (91\%). Most (84\%) disagree with the statement that it makes no difference how their utility gets its electricity, and $83 \%$ trust the utility to make good decisions on the selection and development of new power sources.

Results from another survey question showed that a majority of these respondents give a generally favorable rating to their utility (64\%). A moderate relationship was found between satisfaction with the utility and support for adding new renewables. Those giving highest approval to their utility most strongly supported the idea of the utility adding new renewables. Both commercial and residential customers follow this pattern.

Also, residential customers who give the highest rating to the utility company's overall performance are more likely to say they are "very willing" to voluntarily pay more for renewables than all other respondents. They also are more likely to trust their utility to make decisions and to care about how their utility gets electricity. This suggests that, among very willing respondents, there is a higher level of trust in the utility company than among others. Residential customers less willing to pay more for renewables are twice as likely to say something negative about the utility company than those who say they would probably or definitely spend an additional \$5. Negative comments about the utility included high rates and frequent outages.

A different question showed that greenpricing program participants are significantly more likely than customers at large to assign very high importance to having a utility that gets some of its electricity from green sources (mean scores of 9.1 and 7.3, respectively, on a 1-10 scale).

Results from still another question found that green-pricing program participants are significantly more loyal to the utility company than are customers as a whole. Only 3\% of green-pricing participants say they would switch utility companies, and $17 \%$ say they might switch, compared with $40 \%$ of customers as a whole who say they would (16\%) or might (24\%) switch. In comparison, $34 \%$ of all respondents had switched long-distance telephone companies in the last year.

Three other survey questions explored respondent selection criteria for power providers if there were competition. One of these showed that 9 in 10 customers would choose as their electric company the one who has taken steps to provide more renewable energy resources. A second one showed that $87 \%$ of respondents say a "very important" or "somewhat important" factor in choosing their electric provider is a higher percentage of power from renewable sources than from conventional sources. Ninety percent of respondents to the question say that providing $100 \%$ renewables is most important while $85 \%$ say the same for clean-burning natural gas. When asked which company they would choose (when price is not mentioned), $63 \%$ of the respondents say they would choose the company that generates $80 \%$ of its power from renewables, $22 \%$ say it wouldn't matter, and $7 \%$ don't know. 
Responses to the third question showed that criteria for selecting a green-power provider centers around price, environmental benefits, and credentials of the provider (including general reputation and specific experience with clean, renewable energy). Responses are summarized in Table D-1.

Table D-1. Importance of Green-Power Provider Attributes

\begin{tabular}{|l|c|}
\hline Attributes & $\%$ \\
\hline Is trustworthy/reliable & 74 \\
\hline $\begin{array}{l}\text { Has experience with clean/renewable } \\
\text { energy }\end{array}$ & 64 \\
\hline Experienced/been around a long time & 62 \\
\hline Is located in your state & 48 \\
\hline Is a company you are familiar with & 48 \\
\hline Is a leader in the industry & 47 \\
\hline Is your current provider & 42 \\
\hline
\end{tabular}

